\title{
Superoxide dismutase (EC 1.15.1.1), manganese and the effect of ethanol in adult and foetal rats
}

\author{
By I. E. DREOSTI, SUSAN J. MANUEL AND R. A. BUCKLEY \\ CSIRO Division of Human Nutrition, Adelaide, South Australia 5000, Australia
}

(Received 16 February 1982 - Accepted 5 May 1982)

\begin{abstract}
1. The activity of manganese-superoxide dismutase $(E C 1.15,1.1$; SOD) was increased in the livers and kidneys of adult rats after exposure to aqueous ethanol $(200 \mathrm{ml} / \mathrm{l})$ for 32 weeks.

2. The concentration of $\mathrm{Mn}$ in the livers and kidneys was significantly higher after 24 weeks, and by 32 weeks liver copper and zinc levels were lower.

3. The activity of foetal (day 19) liver superoxide dismutase was appreciably higher in offspring from dams receiving ethanol during pregnancy. Quantitatively the response appeared to be almost entirely due to the Mn-SOD form of the enzyme.

4. Maternal alcoholism during pregnancy had no effect on the levels of $\mathrm{Cu}, \mathrm{Mn}$ or $\mathrm{Zn}$ in foetal (day 19) livers.
\end{abstract}

Two metalloenzymes with superoxide dismutase (EC 1.15.1.1; SOD) activity exist in mammalian tissues, one in which manganese is the prosthetic group (Mn-SOD) and the other which contains copper and zinc ( $\mathrm{Cu}, \mathrm{Zn}$-SOD). Intracellularly, the enzyme appears to be compartmentalized, and in the rat most $\mathrm{Cu}, \mathrm{Zn}$-SOD activity is found in the cytosol, while Mn-SOD seems to be located in the mitochondrial matrix space (Tyler, 1975).

Both forms of the enzyme are important in protecting biomembranes against oxidative damage by naturally-occurring superoxide radicals (Fridovich, 1975), and both enzymes appear to be inducible and respond rapidly to the challenge of increased levels of superoxide radicals (Stevens \& Autor, 1977; Utsumi et al. 1977; Vanella et al. 1981). Very little is known however concerning the relative response of the two enzymes, or of conditions which might favour the synthesis of one particular metalloenzyme form.

The superoxide anion is generated naturally from a variety of cellular reactions and has been supposed to arise during the metabolism of ethanol by microsomal NADPH oxidase, aldehyde oxidase (EC 1 .2.3.1) and NADPH-cytochrome $P 450$ reductase $(E C$ 1.6.2.4) (Cederbaum et al. 1977; Valenzuela et al. 1980). Indeed, increased superoxide dismutase activity resulting from ingestion of ethanol was first reported in foetal rat livers following maternal intoxication during pregnancy (Dreosti \& Record, 1979) and subsequently in adult rat livers after a single dose of ethanol (Valenzuela et al. 1980) and in erythrocytes from human alcoholics (Del Villano et al. 1979).

Chronic alcoholism has been shown to increase hepatic Mn levels in rats (Barak et al. 1967) and the possibility therefore exists that the form of superoxide dismutase induced by ethanol may be the Mn-SOD enzyme. Evidence in support of this view was recently presented by Dreosti et al. (1981) who reported that prolonged alcoholism in adult rats led to increased levels of $\mathrm{Mn}$ in the liver and to enhanced activity of superoxide dismutase, which was principally attributed to the Mn-SOD species.

The present study undertook to examine the effect of extended alcoholism in adult rats on the activity of both forms of superoxide dismutase in a variety of organs, as well as on the distribution of $\mathrm{Cu}, \mathrm{Mn}$ and $\mathrm{Zn}$ in these tissues. In addition, increased activity of foetal superoxide dismutase following maternal alcoholism was studied in greater detail, in order to establish the form of the enzyme principally responsible for the enhanced activity reported in the earlier study. 


\section{METHODS}

\section{Adult studies}

Four groups of four female rats of the Hooded Wistar strain weighing approximately $220 \mathrm{~g}$ were housed individually in stainless-steel and plastic cages and fed ad lib. a commercial diet (W. Charlick \& Son Ltd, Adelaide, South Australia), which contained on analysis (mg/kg diet): $13 \mathrm{Cu}, 91 \mathrm{Mn}, 82 \mathrm{Zn}$. Two groups of animals received aqueous ethanol $(200 \mathrm{ml} / \mathrm{l})$ instead of water as the drinking fluid. Food intake of the animals consuming ethanol fell initially by approximately $30 \%$ but recovered to between 80 and $90 \%$ of the original consumption within $5 \mathrm{~d}$. At this stage the reduction in food energy was almost entirely balanced by the intake of energy associated with ethanol. After 24 or 32 weeks, animals were killed with diethyl ether and measurements were made of the activity of superoxide dismutase in the liver, kidney, heart and brain, together with analyses of the concentrations of $\mathrm{Cu}, \mathrm{Mn}$ and $\mathrm{Zn}$.

\section{Foetal studies}

Two groups of six adult females were mated and day 0 of pregnancy was established by vaginal smear. One group received aqueous ethanol $(200 \mathrm{ml} / \mathrm{l})$ as their drinking fluid throughout pregnancy and all animals were housed as described earlier. On day 19 of gestation foetuses were removed by Caesarean section and the activity of hepatic superoxide dismutase was assayed together with the levels of $\mathrm{Cu}, \mathrm{Mn}$ and $\mathrm{Zn}$ in the foetal livers. Livers from the foetuses of each dam were pooled and divided into two, to allow twelve $(2 \times 6)$ samples to be assayed in duplicate in each instance.

\section{Laboratory procedures}

Superoxide dismutase was assayed by the photochemical augmentation method described by Misra \& Fridovich (1977), which is based on the increased photo-oxidation of dianisidine by riboflavin in the presence of the enzyme. The cyanide-insensitive form (Mn-SOD) was measured as the residual superoxide dismutase activity in the presence of a final concentration of $5.0 \mathrm{~mm}$-sodium cyanide (Fridovich, 1975).

Protein was assayed by the method of Lowry et al. (1951). $\mathrm{Cu}$ and $\mathrm{Zn}$ were measured by flame atomic absorption spectroscopy and $\mathrm{Mn}$ by carbon furnace analysis using a Perkin Elmer 5000 atomic absorption spectrophotometer with an $\mathrm{HG} 500$ furnace attachment (Perkin Elmer Ltd, Melbourne). All results were evaluated using Student's $t$ test (Diem, 1962).

\section{RESULTS AND DISCUSSION}

\section{Adult studies}

Consumption of ethanol by rats for a period of 24 weeks had no significant effect on the level of total or cyanide-insensitive superoxide dismutase in the liver, kidney, heart or brain (Table 1). By 32 weeks, however, increased activity was observed in the livers and kidneys of the ethanol-treated animals. Both the total SOD activity as well as the contribution by the cyanide-insensitive (Mn-SOD) fraction were significantly raised $(P<0.05)$ in both organs, which confirms and extends the earlier reports by Dreosti \& Record (1979), Valenzuela et al. (1980) and Dreosti et al. (1981). No effect was evident at 32 weeks in the heart or brain.

Individual activities of $\mathrm{Cu}, \mathrm{Zn}$-SOD and $\mathrm{Mn}-\mathrm{SOD}$ indicated that the mangano-form of the enzyme occurred at substantially higher levels in the kidney and heart but that it was proportionally much less active in the brain, which is in accord with the findings of Thomas et al. (1976), Paynter (1980) and Vanella et al. (1981). On the other hand, the level of Mn-SOD 


\section{Table 1. Superoxide dismutase (EC 1.15.1.1) in tissues from adult rats exposed to ethanol for 24 and 32 weeks*}

(Mean values with their standard errors for four animals/group)

\begin{tabular}{|c|c|c|c|c|c|c|}
\hline \multirow[b]{3}{*}{ Tissue } & \multirow{3}{*}{$\begin{array}{l}\text { Duration of } \\
\text { experiment } \\
\text { (weeks) }\end{array}$} & \multirow{3}{*}{$\begin{array}{l}\text { Alcohol } \\
\text { status }\end{array}$} & \multicolumn{4}{|c|}{$\begin{array}{l}\text { Activity of superoxide dismutase } \\
\text { (units } \dagger \text { of enzyme activity/mg protein) }\end{array}$} \\
\hline & & & \multicolumn{2}{|c|}{ Total } & \multicolumn{2}{|c|}{ Cyanide-insensitive } \\
\hline & & & Mean & SE & Mean & $\mathrm{SE}$ \\
\hline Liver & $\begin{array}{l}24 \\
24 \\
32 \\
32\end{array}$ & $\begin{array}{l}\text { Control } \\
\text { Alcoholic } \\
\text { Control } \\
\text { Alcoholic }\end{array}$ & $\begin{array}{c}9.0 \\
9.4 \\
9.6 \\
12.6 \$\end{array}$ & $\begin{array}{l}0.7 \\
1.9 \\
0.8 \\
0.4\end{array}$ & $\begin{array}{l}1 \cdot 7 \\
2 \cdot 4 \\
2 \cdot 0 \\
5 \cdot 5 \ddagger\end{array}$ & $\begin{array}{l}0.5 \\
1.2 \\
1.5 \\
0.4\end{array}$ \\
\hline Kidney & $\begin{array}{l}24 \\
24 \\
32 \\
32\end{array}$ & $\begin{array}{l}\text { Control } \\
\text { Alcoholic } \\
\text { Control } \\
\text { Alcoholic }\end{array}$ & $\begin{array}{l}22 \cdot 7 \\
22 \cdot 1 \\
22 \cdot 6 \\
26 \cdot 1 \|\end{array}$ & $\begin{array}{l}1.9 \\
1.2 \\
1.1 \\
1.9\end{array}$ & $\begin{array}{l}16 \cdot 8 \\
18 \cdot 3 \\
15 \cdot 4 \\
19.08\end{array}$ & $\begin{array}{l}3 \cdot 3 \\
1 \cdot 1 \\
0 \cdot 1 \\
0 \cdot 4\end{array}$ \\
\hline Heart & $\begin{array}{l}24 \\
24 \\
32 \\
32\end{array}$ & $\begin{array}{l}\text { Control } \\
\text { Alcoholic } \\
\text { Control } \\
\text { Alcoholic }\end{array}$ & $\begin{array}{l}6.4 \\
6.5 \\
6.1 \\
5.9\end{array}$ & $\begin{array}{l}1.8 \\
0.7 \\
0.6 \\
1.0\end{array}$ & $\begin{array}{l}4.6 \\
5 \cdot 6 \\
3.9 \\
3 \cdot 5\end{array}$ & $\begin{array}{l}0.6 \\
0.7 \\
0.6 \\
0.3\end{array}$ \\
\hline Brain & $\begin{array}{l}24 \\
24 \\
32 \\
32\end{array}$ & $\begin{array}{l}\text { Control } \\
\text { Alcoholic } \\
\text { Control } \\
\text { Alcoholic }\end{array}$ & $\begin{array}{l}2.9 \\
3 \cdot 2 \\
3.5 \\
3 \cdot 0\end{array}$ & $\begin{array}{l}0.9 \\
0.3 \\
0.2 \\
0.4\end{array}$ & $\begin{array}{l}0.6 \\
0 \cdot 5 \\
0 \cdot 7 \\
0.6\end{array}$ & $\begin{array}{l}0 \cdot 3 \\
0 \cdot 3 \\
0 \cdot 2 \\
0 \cdot 2\end{array}$ \\
\hline
\end{tabular}

* For details of diets and experimental procedures, see p. 206.

$\dagger$ One unit of superoxide dismutase activity is defined as the amount of enzyme required to inhibit the rate of reduction of cytochrome $c$ by $50 \%$ under defined conditions (McCord \& Fridovich, 1969).

$\ddagger P<0.05,32$-week alcoholic $v$. 32-week control.

$\| \cdot 1>P>0.05,32$-week alcoholic $v$. 32-week control.

$\S P<0.01,32$-week alcoholic $v$. 32-week control.

in the liver was found to be approximately one-quarter that of the $\mathrm{Cu}, \mathrm{Zn}$-SOD which is similar to the relative amounts quoted by Balevska et al. (1981) but rather less than the value reported by Paynter (1980).

Trace element analyses for $\mathrm{Cu}, \mathrm{Mn}$ and $\mathrm{Zn}$ in liver, after 24 weeks of exposure to ethanol, indicated an accumulation of $\mathrm{Mn}$ in the liver and kidney. No other significant changes were observed at this stage (Table 2).

After 32 weeks of treatment, $\mathrm{Mn}$ levels in the liver and kidney remained elevated, but the concentrations of $\mathrm{Cu}$ and $\mathrm{Zn}$ in the liver were now significantly depressed. No change was detected in the levels of the three trace elements in the heart or brain.

The present results are in accord with the report by Dreosti et al. (1981) in which liver and kidney $\mathrm{Mn}$ levels were found to be raised in rats given aqueous ethanol $(200 \mathrm{ml} / \mathrm{l})$ continuously for a period of 12 months. However, in the present study, kidney Cu levels were less decisively reduced than in the earlier investigations, while the trend to lower concentrations of $\mathrm{Zn}$ in the liver was more evident.

From the present results it appears that the effect of ethanol on hepatic Mn occurs within 24 weeks, but that the change in liver $\mathrm{Cu}$ concentration becomes quantitatively significant between 24 and 32 weeks. Since the main increase in liver Mn-SOD also occurs around this time it may be speculated that the accumulation of hepatic $\mathrm{Mn}$, possibly coupled with the decline in liver $\mathrm{Cu}$, plays some part in the enhanced activity of the Mn-SOD fraction. 
Table 2. Trace element concentrations in tissues from adult rats exposed to ethanol for 24 and 32 weeks*

(Mean values with their standard errors for four animals/group)

\begin{tabular}{|c|c|c|c|c|c|c|c|c|}
\hline & \multirow{3}{*}{$\begin{array}{l}\text { Duration of } \\
\text { experiment } \\
\text { (weeks) }\end{array}$} & \multirow{3}{*}{$\begin{array}{l}\text { Alcohol } \\
\text { status }\end{array}$} & \multicolumn{6}{|c|}{ Tissue trace element concentration $(\mu \mathrm{g} / \mathrm{g}$ wet $w \mathrm{t})$} \\
\hline & & & \multicolumn{2}{|c|}{ Copper } & \multicolumn{2}{|c|}{ Manganese } & \multicolumn{2}{|c|}{ Zinc } \\
\hline & & & Mean & SE & Mean & SE & Mean & $\mathbf{S E}$ \\
\hline Liver & $\begin{array}{l}24 \\
24 \\
32 \\
32\end{array}$ & $\begin{array}{l}\text { Control } \\
\text { Alcoholic } \\
\text { Control } \\
\text { Alcoholic }\end{array}$ & $\begin{array}{l}4 \cdot 0 \\
3 \cdot 4 \\
4 \cdot 2 \\
3 \cdot 1 \ddagger\end{array}$ & $\begin{array}{l}0.2 \\
0.3 \\
0.1 \\
0.01\end{array}$ & $\begin{array}{l}1 \cdot 72 \\
1 \cdot 94 \dagger \\
1 \cdot 84 \\
2 \cdot 17 \|\end{array}$ & $\begin{array}{l}0.11 \\
0.04 \\
0.01 \\
0.05\end{array}$ & $\begin{array}{l}26 \cdot 4 \\
25 \cdot 1 \\
26 \cdot 7 \\
23 \cdot 48\end{array}$ & $\begin{array}{l}0.7 \\
0.5 \\
0.5 \\
0.5\end{array}$ \\
\hline Kidney & $\begin{array}{l}24 \\
24 \\
32 \\
32\end{array}$ & $\begin{array}{l}\text { Control } \\
\text { Alcoholic } \\
\text { Control } \\
\text { Alcoholic }\end{array}$ & $\begin{array}{l}15 \cdot 5 \\
13 \cdot 8 \\
16 \cdot 5 \\
14 \cdot 8\end{array}$ & $\begin{array}{l}1 \cdot 1 \\
1 \cdot 2 \\
0 \cdot 4 \\
3 \cdot 1\end{array}$ & $\begin{array}{l}0.49 \\
0.549 \\
0.42 \\
0.46^{* *}\end{array}$ & $\begin{array}{l}0.01 \\
0.01 \\
0.02 \\
0.01\end{array}$ & $\begin{array}{l}27 \cdot 0 \\
28 \cdot 1 \\
26 \cdot 4 \\
28 \cdot 9\end{array}$ & $\begin{array}{l}0.3 \\
1.8 \\
0 \cdot 8 \\
0 \cdot 1\end{array}$ \\
\hline Heart & $\begin{array}{l}24 \\
24 \\
32 \\
32\end{array}$ & $\begin{array}{l}\text { Control } \\
\text { Alcoholic } \\
\text { Control } \\
\text { Alcoholic }\end{array}$ & $\begin{array}{l}4 \cdot 9 \\
5 \cdot 4 \\
4 \cdot 7 \\
4 \cdot 2\end{array}$ & $\begin{array}{l}0.1 \\
0.3 \\
0.1 \\
0.5\end{array}$ & $\begin{array}{l}0.27 \\
0.29 \\
0.26 \\
0.26\end{array}$ & $\begin{array}{l}0.02 \\
0.04 \\
0.02 \\
0.01\end{array}$ & $\begin{array}{l}14 \cdot 7 \\
15 \cdot 2 \\
16 \cdot 1 \\
15 \cdot 1\end{array}$ & $\begin{array}{l}0.3 \\
0.4 \\
0 \cdot 1 \\
0.8\end{array}$ \\
\hline Brain & $\begin{array}{l}24 \\
24 \\
32 \\
32\end{array}$ & $\begin{array}{l}\text { Control } \\
\text { Alcoholic } \\
\text { Control } \\
\text { Alcoholic }\end{array}$ & $\begin{array}{l}2 \cdot 7 \\
2 \cdot 6 \\
2 \cdot 5 \\
2 \cdot 6\end{array}$ & $\begin{array}{l}0.1 \\
0.1 \\
0 \cdot 1 \\
0.2\end{array}$ & $\begin{array}{l}0.24 \\
0.27 \\
0.29 \\
0.27\end{array}$ & $\begin{array}{l}0.02 \\
0.03 \\
0.03 \\
0.02\end{array}$ & $\begin{array}{l}13 \cdot 7 \\
12 \cdot 9 \\
13 \cdot 8 \\
13 \cdot 4\end{array}$ & $\begin{array}{l}0.2 \\
0 \cdot 8 \\
0 \cdot 2 \\
0 \cdot 1\end{array}$ \\
\hline
\end{tabular}

* For details of diets and experimental procedures, see p. 206.

$\dagger 0.1>P>0.05,24$-week alcoholic $v$. 24-week control.

$\ddagger P<0 \cdot 0005,32$-week alcoholic $v$. 32-week control.

$\| P<0.01,32$-week alcoholic $v$. 32-week control.

$\S P<0.05,32$-week alcoholic v. 32-week control.

If $P<0.01,24$-week alcoholic $v$. 24-week control.

** $0.01>P>0.05$, 32-week alcoholic $v$. 24-week control.

Indeed, it may be that both forms of superoxide dismutase are responsive to induction by superoxide radicals associated with the metabolism of ethanol, but that the species of the enzyme which predominates depends to some extent on the availability of the prosthetic cation at the time of induction. Since under normal conditions it appears that there is very little free $\mathrm{Cu}$ in rat liver tissue, and that the $\mathrm{Cu}, \mathrm{Zn}$-SOD enzyme which accounts for approximately $40 \%$ of the total hepatic $\mathrm{Cu}$ is readily reduced by a fall in liver $\mathrm{Cu}$ status (Paynter, 1981), it is possible that a stimulus for enhanced synthesis of superoxide dismutase in the presence of declining liver $\mathrm{Cu}$ levels but adequate $\mathrm{Mn}$, may favour the induction of the Mn-SOD form of the enzyme.

\section{Foetal studies}

Consumption of ethanol by pregnant dams from days 0-19 of pregnancy resulted in significantly elevated levels of total superoxide dismutase and Mn-SOD in foetal rat livers (Table 3). Quantitatively, it appears that the increase in the activity of superoxide dismutase in the foetal livers is derived almost entirely from enhanced activity of the Mn-SOD which confirms and extends the earlier report by Dreosti \& Record (1979).

No significant changes were observed with respect to the levels of $\mathrm{Cu}, \mathrm{Mn}$ or $\mathrm{Zn}$ in the livers of foetuses from dams consuming ethanol during pregnancy. Superficially, these results do not appear to support the idea advanced earlier of a possible relationship between 


\section{Table 3. Superoxide dismutase (EC 1.15.1.1) in foetal livers from dams receiving ethanol during gestation*}

(Mean values with their standard errors for twelve groups of foetuses/treatment)

\begin{tabular}{|c|c|c|c|c|}
\hline \multirow[b]{3}{*}{ Treatment } & \multicolumn{4}{|c|}{$\begin{array}{l}\text { Activity of superoxide dismutase } \\
\text { (units† enzyme activity/mg protein) }\end{array}$} \\
\hline & \multicolumn{2}{|c|}{ Total } & \multicolumn{2}{|c|}{ Cyanide-insensitive } \\
\hline & Mean & SE & Mean & $\mathbf{S E}$ \\
\hline Control & $5 \cdot 32$ & 0.89 & $2 \cdot 86$ & 0.56 \\
\hline Ethanol-treated & $8.59 \ddagger$ & 1.45 & $5.52 \ddagger$ & 0.98 \\
\hline
\end{tabular}

* For details of diets and experimental procedures, see p. 206.

$\dagger$ One unit of superoxide dismutase activity is defined as the amount of enzyme required to inhibit the rate of reduction of cytochrome $c$ by $50 \%$ under defined conditions (McCord \& Fridovich, 1969).

$\ddagger P<0.05$, ethanol-treated $v$. control.

Table 4. Trace element levels in foetal rat livers from dams exposed to ethanol during pregnancy*

(Mean values with their standard errors for twelve groups of foetuses/treatment)

\begin{tabular}{|c|c|c|c|c|c|c|}
\hline \multirow[b]{3}{*}{ Treatment } & \multicolumn{6}{|c|}{ Liver trace element concentration $(\mu \mathrm{g} / \mathrm{g}$ wet wt) } \\
\hline & \multicolumn{2}{|c|}{ Copper } & \multicolumn{2}{|c|}{ Manganese } & \multicolumn{2}{|c|}{ Zinc } \\
\hline & Mean & $\mathbf{S E}$ & Mean & SE & Mean & SE \\
\hline Control & $18 \cdot 4$ & 1.6 & 0.14 & 0.02 & $45 \cdot 6$ & $1 \cdot 1$ \\
\hline Ethanol-treated & $19 \cdot 7$ & $1 \cdot 1$ & $0 \cdot 17$ & 0.02 & $47 \cdot 9$ & $1 \cdot 5$ \\
\hline
\end{tabular}

* For details of diets and experimental procedures, see p. 206.

raised levels of $\mathrm{Mn}-\mathrm{SOD}$ and reduced concentrations of $\mathrm{Cu}$ in the livers of ethanol-treated, adult rats. Nevertheless, it should be noted that in the foetus more than $80 \%$ of hepatic $\mathrm{Cu}$ occurs in the form of the storage protein mitochondrocuprein, which is located principally in the mitochondrial and nuclear fractions (Underwood, 1977), although more important lysozomal localization has been suggested (Walravens, 1980). It may therefore be that although foetal liver $\mathrm{Cu}$ levels are high in both groups the amount of $\mathrm{Cu}$ available for the synthesis of $\mathrm{Cu}, \mathrm{Zn}$-SOD is limited and the Mn-SOD form of the enzyme is thus favoured.

The increased activity of superoxide dismutase observed in rat foetuses from dams receiving ethanol during pregnancy must raise the question whether the response in part represents a protective mechanism against superoxide radicals produced within the foetus following some extent of in utero metabolism of ethanol or acetaldehyde by the foetal liver. The over-all increase in enzyme activity supports the view expressed earlier (Dreosti \& Record, 1979) that the metabolism of ethanol in the foetus seems to occur to some extent through the microsomal ethanol-oxidizing system, as it is this pathway that is principally responsible for the generation of the superoxide radical (Cederbaum et al. 1977; IngelmanSunderberg \& Johansson, 1981). Moreover, the level of activity of alcohol dehydrogenase in the rat foetus is generally considered to be very low (Horton \& Mills, 1979). 
Overall, the findings raise the question of whether superoxide-related damage may in part be responsible for the foetal alcohol syndrome, and whether the danger might be reduced by manipulation of the maternal trace element status. At this stage such associations are highly speculative, but the demonstrated effect of maternal alcoholism on foetal Mn-SOD must in any event focus attention on the importance of this enzyme during in utero development.

\section{REFERENCES}

Balevska, P. S., Russanov, E. M. \& Kassabova, T. A. (1981). Int. J. Biochem. 13, 489.

Barak, A. J., Beckenhauser, H. C. \& Kerrigan, F. J. (1967). Gut 8, 454.

Cederbaum, A. I., Dicker, E., Rubin, E. \& Cohen, G. (1977). Biochem. biophys. Res. Comm. 78, 1254.

Del Villano, B. C., Tischfield, J. A., Schacter, L. P., Stilwil, D. \& Miller, S. I. (1979). Alcoholism clin. expt. Res. 3, 291.

Diem, K. (editor) (1962). Documenta Geigy, Scientific Tables, p. 165. Basle: Geigy, S. A.

Dreosti, I. E. \& Record, I. R. (1979). Br. J. Nutr. 41, 399.

Dreosti, I. E., Record, I. R., Buckley, R. A., Manuel, S. J. \& Fraser, F. J. (1981). In Trace Element Metabolism in Man and Animals (TEMA-4), p. 617 [J. McC. Howell, J. M. Gawthome and C. L. White, editors]. Canberra: Australian Academy of Science.

Fridovich, I. (1975). A. Rev. Biochem. 44, 147.

Horton, A. A. \& Mills, D. J. (1979). Mechan. Ageing Develop. 11, 363.

Ingelman-Sunderberg, M. \& Johansson, I. (1981). J. biol. Chem. 256, 6321.

Lowry, O. H., Rosebrough, N. J., Farr, A. L. \& Randall, R. J. (1951). J. biol. Chem. 193, 265.

McCord, J. M. \& Fridovich, I. (1969). J. biol. Chem. 244, 6049.

Misra, H. P. \& Fridovich, I. (1977). Archs Biochem. Biophys. 181, 308.

Paynter, D. L. (1980). J. Nutr. 110, 437.

Paynter, D. L. (1981). Copper, manganese, selenium and vitamin E interactions in the rat. PhD Thesis, University of Western Australia.

Stevens, J. B. \& Autor, A. P. (1977). Lab. Invest. 32, 470.

Thomas, T. N., Priest, D. G. \& Zump, J. W. (1976). J. Neurochem. 27, 309.

Tyler, D. D. (1975). Biochem. J. 147, 493.

Underwood, E. J. (1977). Trace Elements in Human and Animal Nutrition, 4th ed. New York: Academic Press. Utsumi, K., Yoshioka, T., Yamanaka, N. \& Nakazawa, T. (1977). FEBS Lett. 79, 1.

Valenzuela, A., Fernandez, V., Fernandez, G., Ugarte, G. \& Videla, L. A. (1980). FEBS Lett. $111,11$.

Vanella, A., Pinturo, R., Grimaldi, R., Tiriolo, P., Di Silvestro, I., Grasso, M., D'Urso, G. \& Geremia, E. (1981). IRCS Med. Sci. 9, 144.

Walravens, P. A. (1980). Clin. Chem. 26, 185. 